\title{
Photoelectrochemical Cell Study on Closely Arranged Vertical Nanorod Bundles of CdSe and Zn doped CdSe Films
}

\author{
D. Soundararajan, J. K. Yoon, J. S. Kwon, Y. I. Kim, S. H. Kim, J. H. Park, Y. J. Kim, D.-Y. Park, ${ }^{\dagger}$ B. C. Kim, \\ G. G. Wallace, ${ }^{\dagger}$ and J. M. Ko ${ }^{*}$ \\ Division of Applied Chemistry \& Biotechnology, Hanbat National University, Daejeon 305-719, Korea \\ *E-mail:jmko@hanbat.ac.kr \\ ${ }^{\dagger}$ Department of Applied Materials Engineering, Hanbat National University, Daejeon 305-719, Korea \\ ${ }^{*}$ ARC Centre of Excellence for Electromaterials Science and Intelligent Polymer Research Institute, \\ University of Wollongong, Northfields Avenue, Wollongong, NSW 2522, Australia \\ Received April 13, 2010, Accepted June 8, 2010
}

\begin{abstract}
Closely arranged $\mathrm{CdSe}$ and $\mathrm{Zn}$ doped $\mathrm{CdSe}$ vertical nanorod bundles were grown directly on FTO coated glass by using electrodeposition method. Structural analysis by XRD showed the hexagonal phase without any precipitates related to $\mathrm{Zn}$. FE-SEM image showed end capped vertically aligned nanorods arranged closely. From the UV-vis transmittance spectra, band gap energy was found to vary between 1.94 and $1.98 \mathrm{eV}$ due to the incorporation of Zn. Solar cell parameters were obtained by assembling photoelectrochemical cells using CdSe and CdSe:Zn photoanodes, Pt cathode and polysulfide $\left(1 \mathrm{M} \mathrm{Na}_{2} \mathrm{~S}+1 \mathrm{M} \mathrm{S}+1 \mathrm{M} \mathrm{NaOH}\right)$ electrolyte. The efficiency was found to increase from 0.16 to $0.22 \mathrm{upon} \mathrm{Zn}$ doping. Electrochemical impedance spectra (EIS) indicate that the charge-transfer resistance on the FTO/CdSe/polysulfide interface was greater than on FTO/CdSe:Zn/polysulfide. Cyclic voltammetry results also indicate that the FTO/ $\mathrm{CdSe}: \mathrm{Zn} /$ polysulfide showed higher activity towards polysulfide redox reaction than that of FTO/CdSe/polysulfide.
\end{abstract}

Key Words: CdSe \& CdSe:Zn nanorod bundled film, Electrodeposition, Photoelectrochemical cell study, Electrochemical impedance \& voltammetric studies

\section{Introduction}

One dimensional nanostructure semiconductors have attracted widespread attention because of their special structure, optical, and electronic transport properties arising from the quantum confinement of electrons. ${ }^{1-3}$ They show size dependent structural, morphological, optical and electrical properties, which make them potential candidates for different applications such as solar cells, light emitting diodes and field emitters. ${ }^{4-6}$ These days, research on dye sensitized solar cells with semiconductor sensitizers and dual sensitizers are getting special attention for the next generation photovoltaic devices owing to its low cost and simple fabrication procedure. ${ }^{7-9}$ Cadmium chalcogenide based one dimensional nano rods are very promising materials for the fabrication of photoelectrochemical cells in order to make use it as semiconductor sensitizer or else in dual sensitized cells. ${ }^{8,9}$ Upon illumination, electrons are injected from the conduction band of the photoexcitated semiconductor (inorganic sensitizer) into FTO, while holes shuttle toward the Pt cathode through a polysulfide redox electrolyte. Hence the synthesis of semiconducting nanostructures and studying its photocurrent using PEC sandwich structure is essential. The research on CdSe and $\mathrm{Zn}$ doped $\mathrm{CdSe}$ nanostructures are getting attention due to its direct optical band gap. ${ }^{10-12}$ Doping by $\mathrm{Zn}$ can tune the band gap of CdSe and which can vary its optical response and it favor the photocurrent conversion efficiency. ${ }^{13}$ Among various nanostructures, the growth of vertically aligned one dimensional nanorods/nanowires is one of the major challenges. As far as this, several kinds of techniques have been utilized to fabricate nanoscale materials, such as molecular beam epitaxy, ${ }^{14}$ sputter- ing, ${ }^{15}$ chemical vapor deposition, ${ }^{16}$ spray pyrolysis, ${ }^{17}$ pulsed laser deposition, ${ }^{18}$ anodic alumina oxide (AAO) template, ${ }^{19}$ cathodic electrodeposition ${ }^{20}$ and aqueous solution deposition methods. ${ }^{21}$ Among various methods, electrodeposition technique is emerged as a competitive technique for the fabrication of nanostructured semiconducting films. Significant advantages of this method are controllable size, morphology, composition, low temperature growth, cost-effectiveness, and less complicated. In the present work, we report the growth, structure, composition, morphology and optical properties of vertically aligned $\mathrm{CdSe}$ and $\mathrm{Zn}$ doped $\mathrm{CdSe}$ nanorod bundles grown directly on FTO coated glass. Also, we studied the photoelectrochemical and electrochemical properties of PECs based on CdSe and Zn doped CdSe photoanodes in the sandwich form.

\section{Experimental Details}

Preparation of $\mathrm{CdSe}$ and $\mathrm{Zn}$ doped $\mathrm{CdSe}$ nanorod array fillms. $\mathrm{CdSe}$ and $\mathrm{Zn}$ doped CdSe films were electrodeposited onto FTO film coated glass substrate at $26^{\circ} \mathrm{C}$ by using an aqueous bath. Cadmium acetate $\left[\mathrm{Cd}\left(\mathrm{CH}_{3} \mathrm{COO}\right)_{2}\right]$, zinc acetate $\left[\mathrm{Zn}\left(\mathrm{CH}_{3} \mathrm{COO}\right)_{2}\right]$ and selenium dioxide $\left(\mathrm{SeO}_{2}\right)$ were used as sources of $\mathrm{Cd}, \mathrm{Zn}$ and $\mathrm{Se}$, respectively. The solution contained $47 \mathrm{mM}$ cadmium acetate, $3 \mathrm{mM}$ zinc acetate and $50 \mathrm{mM}$ selenium dioxide for the preparation of $\mathrm{Zn}$ doped CdSe. Similarly, $50 \mathrm{mM} \mathrm{Cd}$ and $50 \mathrm{mM}$ of Se sources were mixed for the preparation of CdSe. Chronopotentiometric technique with constant current density having three-electrode system viz. working, counter, and reference were used with computer based potentiostat (Auto lab, P/GStat 100). Well cleaned working FTO coated glass, Pt counter 
and $\mathrm{Ag} / \mathrm{AgCl}$ reference electrodes were used. A constant current density of $-2 \mathrm{~mA} / \mathrm{cm}^{2}$ was applied for 2000 seconds between the working FTO and Pt counter electrodes in the presence of $\mathrm{Ag} / \mathrm{AgCl}$ reference electrode.

In the case of counter electrode Pt, $41 \mathrm{mg}$ of chloroplatinic acid hydrate $\left(\mathrm{H}_{2} \mathrm{PtCl}_{6}\right)(99.9 \%$, Aldrich) was dissolved in a solvent of $2 \mathrm{~mL} 2$-propanol. The $10 \mu \mathrm{L}$ solution was dropped over FTO substrate and then kept at $400{ }^{\circ} \mathrm{C}$ for 30 minutes in order to get Pt film.

Characterization. Structure of the grown films was done by using powdered X-ray diffraction technique (XRD - Rigaku, D/MAX 2500H) using a $\mathrm{Cu} \mathrm{K} \alpha$ source radiation. The diffractometer was operated in the step scan mode with a step of 0.02 and in the $2 \theta$ range of $20^{\circ}-70^{\circ}$. The elemental composition was determined by using an energy dispersive $\mathrm{x}$-ray analysis (EDS) attached to the field emission-scanning electron microscope (JEOL, JSM-6300). The cross sectional view was performed by using FE-SEM. The optical transmittance spectra were obtained within the spectral range of 300 - $1000 \mathrm{~nm}$ using a UV-vis-spectrophotometer (HP-8453) at room temperature.

Photoelectrochemical cell (PEC) fabrication and efficiency measurement. The as-deposited CdSe and $\mathrm{Zn}$ doped CdSe films were used as photoanode and the solution cast Pt was used as cathode. PEC cell measurements were done for the sandwich of FTO/CdSe/Pt/FTO and FTO/CdSe:Zn/Pt/FTO. The semiconducting photo anodes (FTO coated CdSe and CdSe:Zn) and their respective metal cathodes $(\mathrm{Pt} / \mathrm{FTO})$ were bringing together in contact by means of a bynel thermoplastic film and subsequent heat treatment at $125^{\circ} \mathrm{C}$ for 5 minutes. This provides a sandwich structure and it prevents electrolyte leakage. Internal space between the semiconducting photoanodes and metal cathode was filled with $1 \mathrm{M}$ of polysulfide liquid electrolyte by means of capillary action through the holes drilled over the cathode side. After the injection, the holes were sealed by soldering with a thin cover glass. The active area of the cell was $9 \mathrm{~mm}^{2}$. The solar cell parameters were measured by using Spectral Energy, US/Solar Light source Simulator. The intensity of light was $100 \mathrm{~mW} / \mathrm{cm}^{2}$. The current-voltage curves and the solar cell parameters were obtained by using Solartron, GB/1285A, Potentiostat. Electrochemical impedance and cyclic voltammogram profiles were also recorded for the PECs under dark.

\section{Results and Discussion}

Structure and composition. X-ray diffraction patterns of asdeposited $\mathrm{CdSe}$ and $\mathrm{Zn}$ doped $\mathrm{CdSe}$ films grown on FTO coated glass in the $2 \theta$ scan range of $20^{\circ}$ to $70^{\circ}$ are shown in Fig. 1. Diffraction pattern of CdSe shows peaks at $2 \theta$ angles of $25.54^{\circ}$, $26.35^{\circ}, 38.28^{\circ}$ and $51.38^{\circ}$ along (100), (002), (100), (102) and (004) directions, respectively. This indicates the hexagonal crystal structure. ${ }^{22}$ Further, similar reflections such as (002), (100), (102) and (004) that characterize hexagonal structure are noticed for $\mathrm{Zn}$ doped CdSe. The diffraction peaks are not shifted in the $\mathrm{Zn}$ doped CdSe (relative to the undoped CdSe) presumably because of the rather low doping levels. Interestingly, the as-obtained CdSe and Zn doped CdSe films shows good crystallinity without any $\mathrm{Zn}$ related secondary phases. However, a minute amorphous phase of $\mathrm{CdSe}$ and selenium precipitate

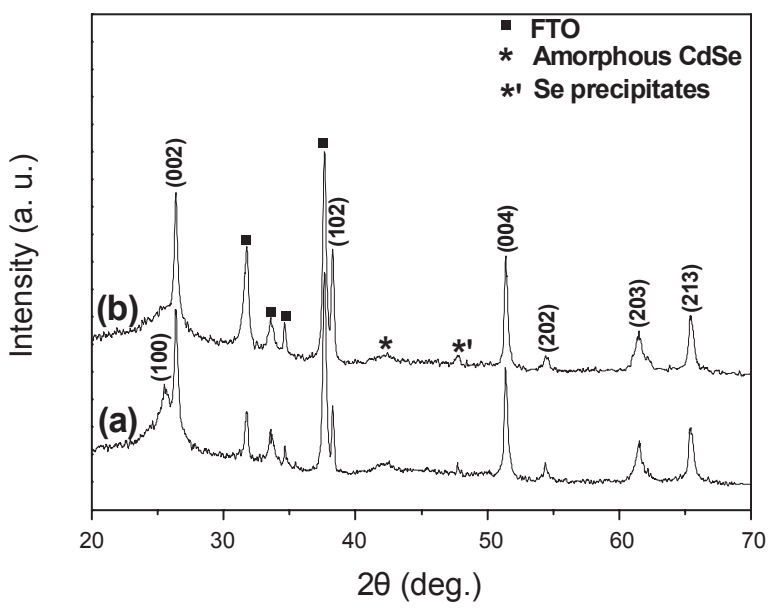

Figure 1. X-ray diffraction patterns of (a) $\mathrm{CdSe}$ and (b) $\mathrm{Zn}$ doped CdSe films grown on FTO coated glass.

(a)

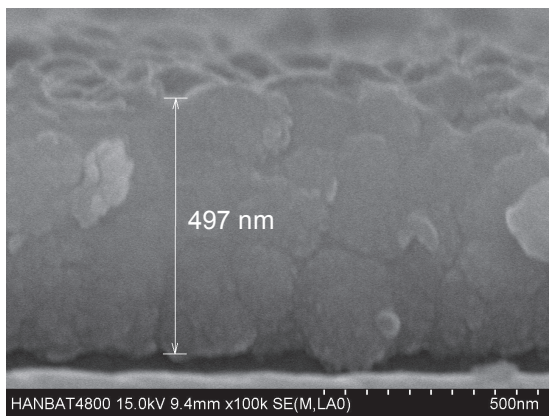

(b)

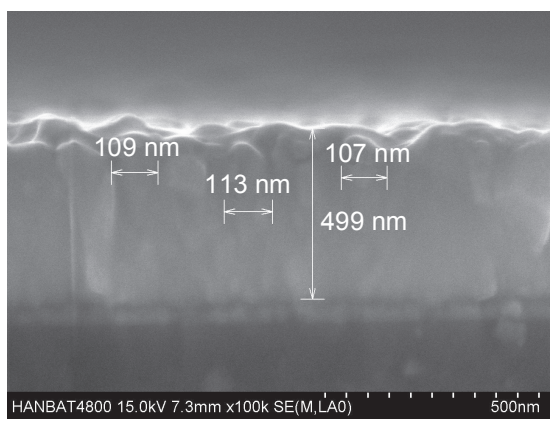

Figure 2. FE-SEM images of CdSe film in (a) plane and (b) cross sectional view and $\mathrm{Zn}$ doped CdSe film in (c) plane and (d) cross sectional view.

are noticed at $42.23^{\circ}$ and $47.9^{\circ}$, respectively. Microstructural parameters such as particle size (D), lattice constants (a, c), strain $(\varepsilon)$ and dislocation density $(\delta)$ of $\mathrm{CdSe}$ and $\mathrm{Zn}$ doped $\mathrm{CdSe}$ films were evaluated by using Debye-Scherrer ${ }^{23-25}$ formula and the full-width at half maximum (FWHM) $\beta$ of diffraction patterns. Scherrer analyses of these XRD data shows a decrease in grain size from 39.56 to $32.94 \mathrm{~nm}$ upon $\mathrm{Zn}$ doping. Also the evaluated values of strain and dislocation density are tends to decrease from $120.6 \times 10^{-3}$ to $111.06 \times 10^{-3} \mathrm{lin}^{-2} \mathrm{~m}^{-4}$ and from

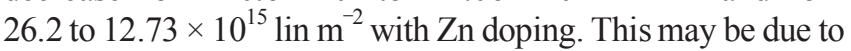
the improvement in the crystallinity of the film upon $\mathrm{Zn}$ doping. The calculated values of lattice parameters such as 'a' and 'c' are $0.402 \AA$ and $0.676 \AA$, respectively. The calculated values of lattice spacing and lattice parameter show good agreement 


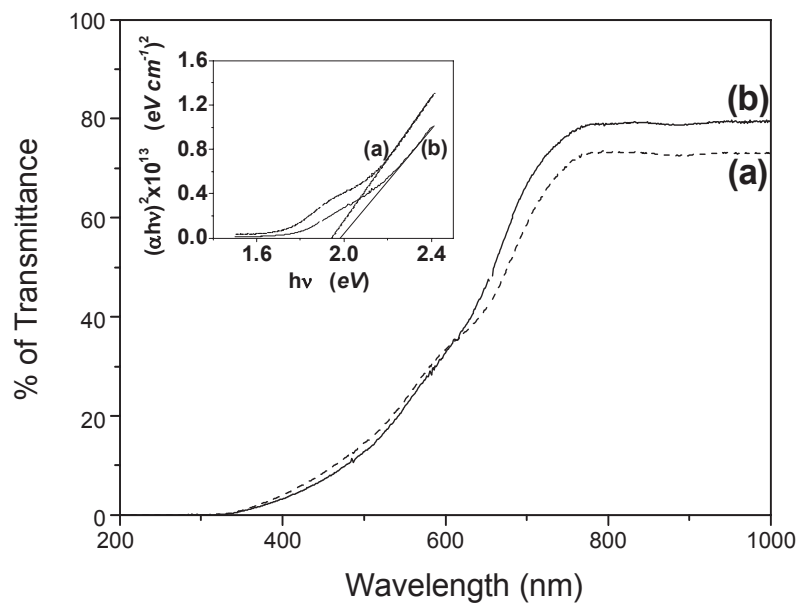

Figure 3. Transmittance spectra of (a) CdSe and (b) Zn doped CdSe films. Inset shows the plot between $(\alpha h v)^{2}$ and $h v$. The obtained value of band gap of CdSe and CdSe:Zn are 1.94 and $1.98 \mathrm{eV}$, respectively.

with the standard card (JCPDS Card File No: 77-2307).

The elemental analysis was done by using EDS spectra attached to FE-SEM. The estimated values of relative atomic percentage of $\mathrm{Cd}$, Se and $\mathrm{Zn}$ elements in $\mathrm{CdSe}$ and $\mathrm{Zn}$ doped CdSe films were 52.03:47.97 and 50.38:47.00:2.62, respectively. The composition analysis showed Se deficiency in the prepared films.

SEM analysis. The cross sectional views of SEM images of $\mathrm{CdSe}$ and $\mathrm{Zn}$ doped $\mathrm{CdSe}$ films are shown in Fig. 2. It showed closely arranged vertically aligned nanorod bundles. In the case of CdSe, the nanorod bundles look grainy and are not smooth. On the other hand, in the case of $\mathrm{Zn}$ doped CdSe, the nanorod bundles are smooth. In both cases, the average length of the nanorod bundles is around $500 \mathrm{~nm}$ and is not changed with $\mathrm{Zn}$ doping. However, the average diameter has been noticed to decrease from 200 to $160 \mathrm{~nm}$ with $\mathrm{Zn}$ doping. Upon comparing the two images, it is clear that the CdSe is relatively rich in voids, cracks and any other serious defects than $\mathrm{Zn}$ doped CdSe. This can be expected from the Se deficiency in CdSe as observed from EDS analysis. However, upon Zn incorporation, these crystal defects such as voids, dislocations as a result of Se vacancy are tends vanish as can be seen from cross sectional images. These observations also reflect the tendency of microstructural parameters obtained from XRD analysis.

Optical transmittance \& band gap. After discussing the structure and morphological studies, we analyze the optical properties that are fundamental for the performance of nanostructured solar cells. Transmittance studies were carried out in the wavelength range of $300-1000 \mathrm{~nm}$ to investigate the optical absorption properties of the $\mathrm{CdSe}$ and $\mathrm{Zn}$ doped $\mathrm{CdSe}$ vertical nanorod bundled films. The obtained results are plotted in Fig. 3 . $\mathrm{CdSe}$ and $\mathrm{CdSe}: \mathrm{Zn}$ nanorod bundles show a change in optical transmittance. These changes are attributed to the structural, compositional, crystallinity and morphological changes taking place when $\mathrm{Zn}$ is incorporated into CdSe lattice. The transmittance of $\mathrm{CdSe}$ is decreased with doping of $\mathrm{Zn}$ compared to undoped $\mathrm{CdSe}$, which correspond to the increasing of intrinsic defects (point defect, dislocation). Fundamental absorption edge
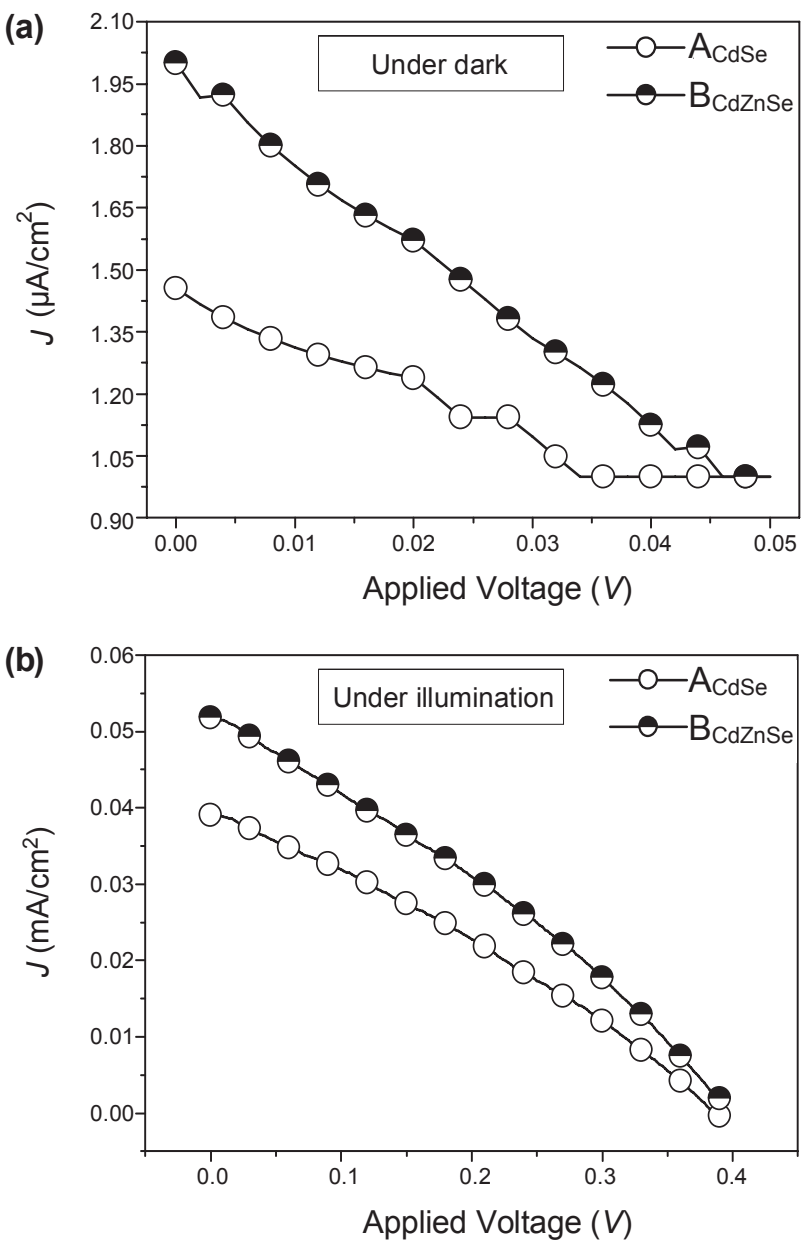

Figure 4. $J-V$ characteristics of $\mathrm{A}_{C d S e}$ and $\mathrm{B}_{C d S e: Z n}$ cells under (a) dark and (b) illumination.

is found to shift towards lower wavelength region (from 736 to $675 \mathrm{~nm}$ ) when $\mathrm{Zn}$ has been introduced into CdSe host. The cause of observed blue shift shall be due to the decrease of $\mathrm{Cd}$ concentration and increase of $\mathrm{Zn}$ concentration in the films. This is because the bandgap of $\mathrm{ZnSe}$ is greater than that of CdSe. The absorption coefficients are calculated using the relation, $\alpha=\frac{2.303 \log (1 / T)}{d}$, where $d$ is film thickness and $T$ is transmittance. The band gap value has been obtained by the plot between $(\alpha h v)^{2}$ and photon energy (hv) as shown in the inset of Fig. 3. The plot between $(\alpha h v)^{2}$ and $h v$ is found to have straight line over any part of the optical absorption spectrum, thus supporting the interpretation of direct allowed transition. ${ }^{26}$ Extrapolation of the linear portion of the curve to $(\alpha h v)^{2}=0$ gives the optical band gap value for the films. It is observed that the direct band gap energy for the undoped CdSe is 1.94 and it increases to $1.98 \mathrm{eV}$ when $\mathrm{Zn}$ is doped into CdSe.

Photoelectrochemical cell study. The fabricated photoelectrochemical cells based on $\mathrm{CdSe}$ (named as $\mathrm{A}_{\mathrm{CdSe}}$ ) and CdSe: $\mathrm{Zn}$ (named as $\mathrm{B}_{\mathrm{CdS}}: \mathrm{Zn}$ ) photoanodes were studied for its photoelectrochemical studies such as current-voltage under dark and illumination. Photocurrent versus applied voltage $(I-V)$ of $\mathrm{A}_{\mathrm{CdSe}}$ and $\mathrm{B}_{\mathrm{CdSe}} \mathrm{Zn}$ cells under dark and light illumination are shown in Fig. 4. It can be seen that under illumination, the magnitude 
Table 1. Solar cell parameters of PECs based on CdSe and CdSe:Zn photoanodes

\begin{tabular}{lcccc}
\hline Cell & $\begin{array}{c}\text { Short circuit current density } \\
\left(\mathrm{mA} / \mathrm{cm}^{2}\right)\end{array}$ & $\begin{array}{c}\text { Open circuit voltage } \\
\mathrm{V}_{\mathrm{oc}}(\mathrm{V})\end{array}$ & Fill factor $(\mathrm{FF})$ & \multicolumn{2}{c}{$\begin{array}{c}\text { Photoconversion eficiency } \\
\eta(\%)\end{array}$} \\
\hline $\mathrm{A}_{\mathrm{CdSe}}$ & 0.0385 & 0.3857 & 0.3128 & 0.16 \\
$\mathrm{~B}_{\mathrm{CdSe}: \mathrm{Zn}}$ & 0.0506 & 0.3969 & 0.3176 & 0.22 \\
\hline
\end{tabular}

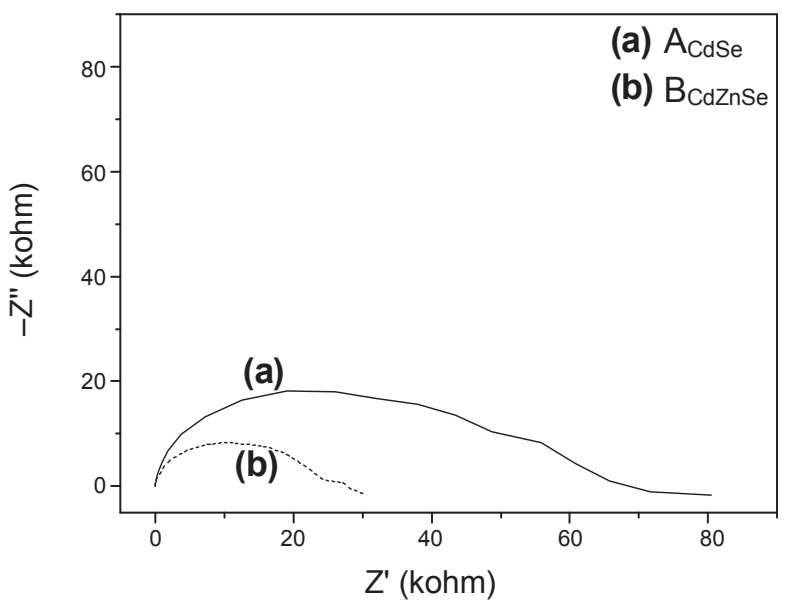

Figure 5. Impedance spectra of (a) $A_{C d S e}$ and (b) $B_{\text {CdSe:zn }}$ cells under dark on Nyquist plane.

of current is found to increase (milli ampere range) and in the absence of light illumination it is insignificant (micro ampere range). The working principle of the present PEC cell can be explained as follows. Under illumination, electrons in the valence band of CdSe or CdSe:Zn semiconducting photoanodes are excited into the conduction band due to the absorption of photons. These electrons will flow to the Pt cathode through the external circuit and offer short circuit current and open circuit voltage. Solar to electrical power conversion efficiency was then obtained by using the relation,

$\eta=$ Output power/Input power

$=[$ Power $/($ Intensity of illumination $\times$ Area illuminated $)] 100 \%$

$D=\left(I_{m} \times V_{m}\right) /\left(P_{r}\right) \times 100$

Where, $I_{m} \times V_{m}$ is the maximum multiplied value in the $I-V$ sweep, $P_{r}$ is the illumination power input $\left(100 \mathrm{~mW} / \mathrm{m}^{2}\right)$ and $\mathrm{A}$ is the effective area of the cell. The solar cell parameters obtained for the as-grown CdSe and $\mathrm{Zn}$ doped CdSe photoanodes are given in Table 1. Upon $\mathrm{Zn}$ doping, the values of short circuit current $\left(\mathrm{J}_{\mathrm{sc}}\right)$ and open circuit voltage $\left(\mathrm{V}_{\mathrm{oc}}\right)$ are found to increase to $0.0506 \mathrm{~mA} / \mathrm{cm}^{2}$ and $0.3969 \mathrm{~V}$, respectively. Consequently the efficiency is found to increase from 0.16 to 0.22 when $\mathrm{Zn}$ is doped. The reason for the observed increment in efficiency can be explained in two ways. The increment in efficiency upon $\mathrm{Zn}$ doping is due to the greater band bending that increase $V_{o c}$ and overall cell performance. ${ }^{29}$ In addition to this, the majority carrier diffusion length in $\mathrm{Zn}$ doped $\mathrm{CdSe}$ is greater than that in CdSe. Because, CdSe has relatively more voids and point defect than in CdSe:Zn and this shall decrease the recombination rate in CdSe:Zn than in CdSe nanorod bundled films. ${ }^{30,31}$

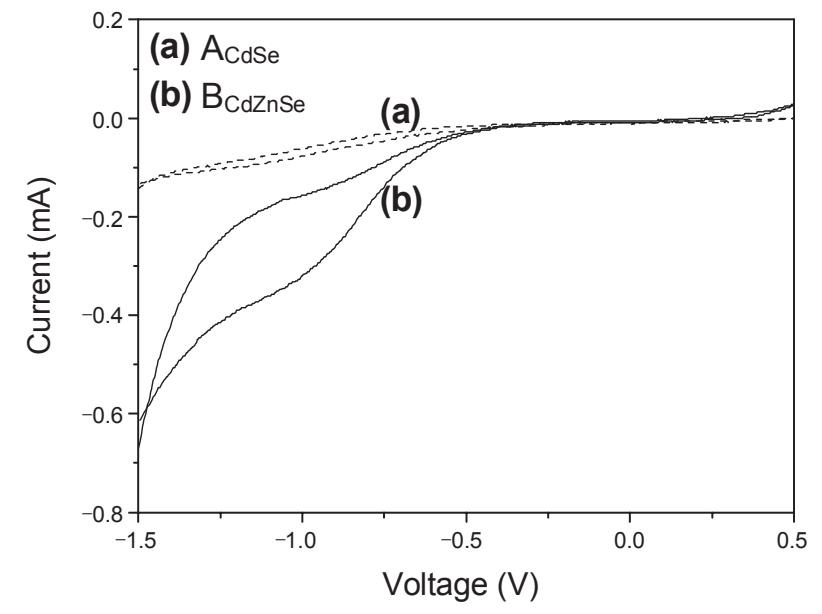

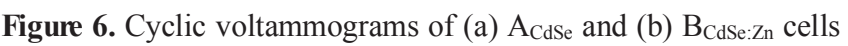
under dark.

Impedance spectra. Electrochemical impedance spectroscopy (EIS) is a very powerful tool for the analysis of changes in interfacial capacitance or resistance occurring at conductive or semiconductive surfaces. ${ }^{32,33}$ In order to compare the interfacial charge transfer between the anode and electrolyte interface, ac impedance spectra on Nyquist plane was recorded under dark over a frequency range of $0.01 \mathrm{~Hz}$ to $0.1 \mathrm{MHz}$ at a voltage of $0.03 \mathrm{~V}$. The obtained results on $\mathrm{A}_{\mathrm{CdSe}}$ and $\mathrm{B}_{\mathrm{CdSe}: \mathrm{Zn}}$ cells are plotted in Nyquist plane as in Fig. 5. In general, impedance spectra can show three semicircles that in the order of increase of frequency are Nernst diffusion within the electrolyte, the charge transfer at the photoanode/polysulfide electrolyte interface and charge transfer at the counter electrode/electrolyte interface. The resultant impedance spectra exhibits one large semicircle in the high and middle frequency range and another smaller overlapping semicircle in the low frequency range. The first large semicircle is the indication of redox reactions at the anode/electrolyte/cathode Pt interfaces. The second smaller semicircle is due to the Nernst diffusion through the electrolyte. Upon comparing the impedance spectra of $\mathrm{A}_{\mathrm{CdSe}}$ and $\mathrm{B}_{\mathrm{CdSe}: \mathrm{Zn}}$ cells, it is clearly seen that $A_{C d S e}$ has larger semicircle than

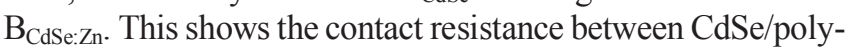
sulfide is slightly greater than $\mathrm{CdSe}: \mathrm{Zn} /$ polysulfide and hence it may suppress the reaction between the conduction band electrons of CdSe with polysulfide redox electrolyte. This leads to the increase in photocurrent of $\mathrm{B}_{\mathrm{CdSe}: \mathrm{Zn}}$ than in $\mathrm{A}_{\mathrm{CdSe}}$ cell.

Cyclic voltammetry. Cyclic voltammetry is a potential tool to know the reduction-oxidation reactions taking place at the interface between the electrodes and electrolyte. ${ }^{34,35}$ It was obtained under dark for $\mathrm{A}_{\mathrm{CdSe}}$ and $\mathrm{B}_{\mathrm{CdSe}} \mathrm{Zn}$ by varying the voltage between $-0.15 \mathrm{~V}$ to $0.5 \mathrm{~V}$ with a scan rate of $5 \mathrm{mVs}^{-1}$. It can be 
seen that, there is no any noticeable redox faradic current for $\mathrm{A}_{\mathrm{CdSe}}$. On the other hand, in the case of $\mathrm{B}_{\mathrm{CdSe}: \mathrm{Zn}}$, the voltammetric profile exhibited broad oxidation-reduction signals with negative current magnitude due to trivial dark current. These results indicate that there is a large resistance between $\mathrm{CdSe} /$ polysulfide than $\mathrm{CdSe}: \mathrm{Zn} /$ polysulfide interface. It results in the relatively good performance of $\mathrm{B}_{\mathrm{CdSe}} \mathrm{Zn}$ than $\mathrm{A}_{\mathrm{CdSe}}$ cell.

\section{Conclusion}

Closely arranged CdSe and $\mathrm{Zn}$ doped CdSe vertical nanorod bundles were grown on FTO glass by using a electrodeposition method. XRD analysis has shown that the as-deposited films were hexagonal nature with good crystallinity and no detectable secondary phase corresponding to $\mathrm{Zn}$ related precipitates is observed upon $\mathrm{Zn}$ doping. FE-SEM investigation has shown closely arranged vertical nanorod bundles and it also indicated the $\mathrm{Zn}$ addition has improved the alignment of nanorod bundles. The band gap values have shown to increase from 1.94 to 1.98 eV with $\mathrm{Zn}$ doping. The PEC cells based on CdSe and $\mathrm{Zn}$ doped CdSe photoanodes were fabricated and the results showed augmentation of efficiency from 0.16 to 0.22 upon $\mathrm{Zn}$ doping under similar circumstances. Electrochemical impedance and cyclic voltammogram measurements under dark showed decrease in contact resistance and consequently improvement in redox faradaic current when $\mathrm{CdSe}: \mathrm{Zn}$ was used as photoanode.

Acknowledgments. This work was supported by the World Class University Program (R33-2008-000-10147-0) from Ministry of Education, Science and Technology, Korea.

\section{References}

1. Kar, J. P.; Kumar, M.; Choi, J. H.; Das, S. N.; Choi, S. Y.; Myoung, J. M. Solid State Commun. 2009, 149, 1337.

2. Zhang, Z. H.; Qi, X. Y.; Jian, J. K.; Duan, X. F. Micron. 2006, 37, 229.

3. Klein, D. L.; Roth, R.; Lim, A. K. L.; Alivisatos, A. P.; McEuen, P. L. Nature 1997, 389, 699.

4. Jeon, M.; Kamisako, K. Mater. Lett. 2009, 63, 777.

5. Luo, L.; Zhang, Y.; Mao, S. S.; Lin, L. Sens. Actuators, A 2006, 127, 201.

6. Sheini, F. J.; Joag, D. S.; More, M. A. Ultramicroscopy 2009, 109, 418.

7. Baxter, J. B.; Aydil, E. S. Sol. Energy Mater. Sol. Cells 2006, 90 ,
607.

8. Bang, J. H.; Kamat, P. V. ACS Nano 2009, 3, 1467.

9. Ganesh, T.; Mane, R. S.; Cai, G.; Jin-Ho, C.; Sung-Hwan, H. J. Phys. Chem. C 2009, 113, 7666.

10. Sun-Ki, M.; Oh-Sim, J.; Kwang-Deog, J.; Mane, R. S.; SungHwan, H. Electrochem. Commun. 2006, 8, 223.

11. Tena-Zaera, R.; Ryan, M. A.; Katty, A.; Hodes, G.; Bastide, S.; Lévy-Clément, C. Comptes Rendus Chimie. 2006, 9, 717.

12. Chavhan, S. D.; Mane, R. S.; Wonjoo, L. ; Senthilarasu, S.; SungHwan, H.; Lee, J.; Soo-Hyoung, L.; Electrochim. Acta 2009, 54 , 3169.

13. Ju-Hyun, A.; Mane, R. S.; Todkar, V. V.; Sung-Hwan, H. Int. J. Electrochem. Sci. 2007, 2, 517.

14. Shen, Q.; Sato, T.; Hashimoto, M.; Chen, C.; Toyoda, T. Thin Solid Films 2006, 499, 299.

15. Park, Y. M.; Andre, R.; Kasprzak, J.; Dang, L. S.; Bellet-Amalric, E. Appl. Surf. Sci. 2007, 253, 6946.

16. Levichev, S.; Chahboun, A.; Basa, P.; Rolo, A. G.; Barradas, N. P.; Alves, E.; Horvath, Zs. J.; Conde, O.; Gomes, M. J. M. Microelectron. Eng. 2008, 85, 2374.

17. H. Chenga, H. Y.; Chaoa, Y. H.; Changa, C. H.; Hsua, C. L.; Chenga, T. T.; Chena, Y. F.; Chena, M. W. Chub, Physica E 2008, 40, 2000.

18. Elango, T.; Subramanian, V.; Murali, K. R. Surf. Coat. Technol. 2000, 123,8 .

19. Hernandez-Perez, M. A.; Aguilar-Hernandez, J.; Contreras-Puente, G.; Vargas-García, J. R.; Rangel-Salinas, E. Physica E 2008, 40, 2535.

20. Wang, X.; Gao-Rong, H. Microelectron. Eng. 2003, 66, 166.

21. Mohamed S. El-Deab Int. J. Electrochem. Sci. 2009, 4, 1329.

22. Mao-Quan, C.; Ye, S.; Xiao-Yan, S.; Guo-Jie, L. Physica. E 2006, 35,75 .

23. Sun-Ki, M.; Oh-Sim, J.; Kwang-Deog, J.; Rajaram, S. M.; SungHwan, H. Electrochem. Commun. 2006, 8, 223.

24. Venkatachalam, S.; Mangalaraj, D.; Narayandass, S. K.; Kim, K.; Yi, J. Physica B 2005, 358, 27.

25. Murali, R.; Jayasuthaa, B. Sol. Energy 2009, 83, 891.

26. Soundararajan, D.; Mangalaraj, D.; Nataraj, D.; Dorosinskii, L.; Santoyo-Salazar, J.; Jeon, H. C.; Kang, T. W. Appl. Surf. Sci. 2009, $255,7517$.

27. Mandal, K. C. J. Mater. Sci. Lett. 1980, 9, 1203.

28. Levy-Clement, C.; Tena-Zaera, R.; Ryan, M. A.; Katty, A.; Hodes, G. Adv. Mater. 2005, 17, 512.

29. Law, M.; Greene, L. E.; Johnson, J. C.; Saykally, R.; Yang, P. Nat. Mater. 2005, 4, 455.

30. Elias, J.; Tena-Zaera, R.; Guillaume-Yangshu, W.; Levy-Clement, C. Chem. Mater. 2008, 20, 6633.

31. Lee, W. J.; Ramasamy, E.; Lee, D. Y.; Song, J. S. ACS Appl. Mater. Interfaces 2009, $1,1145$.

32. Xie, Y. Electrochim. Acta 2006, 51, 3399.

33. Yuh-Lang Lee, B.; Yi-Siou, L. Adv. Funct. Mater. 2009, 19, 604. 